\title{
Entrepreneurial Risk-Taking: Implications From Risk-Sensitivity Theory
}

\author{
Chuanyin Xie \\ The University of Tampa
}

Entrepreneurship is a risky endeavor. Why do some people decide to accept entrepreneurial risks in order to obtain possible financial and non-financial returns? The debate over this question has been going on for decades, but it has never ended. In this study, I join the debate and attempt to answer the question based on risk-sensitivity theory. The main idea behind the theory is that need motivates risk-taking behaviors. I review the literature on entrepreneurial risk-taking and focus on four broad approaches: trait, demographic, environmental, and cognitive. I develop an integrative framework based on risk-sensitivity theory. The framework recognizes the value of different approaches to entrepreneurial risk-taking. At the same time, it also addresses the limitations of each approach if used alone. My central argument is that people take entrepreneurial risks because other less risky options cannot meet their needs.

Keywords: entrepreneurship, risk-taking, risk-sensitivity theory, need

\section{INTRODUCTION}

Risk bearing could be a main distinguishing factor between entrepreneurs and managers (Mill, 1848). Therefore, entrepreneurs have been argued to be the ultimate risk bearers (Leibenstein, 1968). The reason seems straightforward. Entrepreneurship is an activity associated with uncertainty (Townsend et al, 2018). It often generates low median returns but with very high variance (Astebro, et al, 2014). Entrepreneurs thus risk "financial well-being, career opportunities, family relations, and psychic well-being" (Brockhaus, 1980: 510). If entrepreneurs do have to take risks, are they as a group more risk-prone than nonentrepreneurs? Many empirical studies have been conducted, but the results have not been conclusive. Not all entrepreneurs are risk-seeking and some are even risk-averse. Why do they still take risks? The debate has been going on for decades (e.g., Leibenstein, 1968; McClelland, 1961; Palich \& Bagby, 1995). Recently, Zaleskiewicz and colleagues (2020) continued the exploration of entrepreneurs' risk-taking behaviors and contributed to the debate by using a cognitive approach. In this study, I join the debate and develop an integrative framework to reconcile different theoretical approaches.

According to Gartner et al (1994), entrepreneurship is inherently idiosyncratic and there are many different kinds of entrepreneurs. Wortman (1987) also argued that entrepreneurs themselves are different from each other just as they are different from the rest of the population. In this study, therefore, I do not assume entrepreneurs as a group possess some common characteristics that lead them to take risky actions. Instead, I assume entrepreneurs take risks based on situations. I explore those situations and attempt to answer the following question: when do entrepreneurs take risks and under what circumstances? 
The reminder of the paper is organized the following way. First, I review the literature on entrepreneurs' risk-taking behaviors. Second, I introduce risk-sensitivity theory which has traditionally been used to examine the foraging behaviors of animals. Recently, it has been applied in the human context. Third, based on risk-sensitivity theory, I propose a framework integrating different approaches to entrepreneurial risktaking. Finally, I discuss theoretical contributions and future research directions.

\section{LITERATURE REVIEW}

Risk has been a key concept in the entrepreneurship literature. It "occupies the center of most definitions of entrepreneurship" (Palich \& Bagby, 1995: 425) and plays a central role in entrepreneurial decisionmaking (Mullins \& Forlani, 2005). Since entrepreneurship is a risky endeavor, entrepreneurs do need to take a certain amount of risk. However, it is still unclear why some people choose to accept entrepreneurial risks in order to obtain possible financial and non-financial returns (Zaleskiewicz et al, 2020). In this section, I review the literature on entrepreneurial risk-taking. I focus on four broad approaches: trait approach, demographic approach, environmental approach, and cognitive approach. Finally, I discuss limitations of existing approaches to entrepreneurial risk-taking.

\section{Trait Approach}

Early research on entrepreneurial risk-taking has employed a trait approach which suggests that entrepreneurs as a group possess some unique psychological or personality traits that lead them to take risky actions. Hornaday (1982) identified 42 attributes entrepreneurs might possess. Among them, risk-taking propensity has been most frequently cited because it offers a seemingly reasonable explanation for why entrepreneurs take risky actions. In addition, need for achievement, tolerance for ambiguity, and internal locus of control have also been considered to play a role in entrepreneurial risk-taking.

Gasse (1982) argued that risk-taking propensity fundamentally distinguishes entrepreneurs from nonentrepreneurs. However, not all scholars agree that entrepreneurs are natural risk takers. It is more likely that entrepreneurs pursue tasks that are achievable and controllable, so they assess and calculate risks rather than knowingly take risks (McClelland, 1961; Cromie \& O’Domoghue, 1992). Empirical studies have provided mixed results. For example, Stewart and Roth (2001) conducted a meta-analysis and found that entrepreneurs had a higher risk propensity than managers. Miner and Raju (2004) conducted another metaanalysis which added 14 studies not included in Stewart and Roth's (2001) analysis. They found that entrepreneurs including those with growth orientation were actually more risk avoidant. There have also been empirical studies suggesting no significant differences between entrepreneurs and non-entrepreneurs in their propensity to take risks (Brockhaus, 1980; Richard, 1989; Palich \& Bagby, 1995). For example, Brockhaus (1980) compared entrepreneurs and managers based on the Kogan-Wallach choice dilemmas questionnaire and found they were not significantly different in their risk-taking propensity.

Using risk-taking propensity to explain entrepreneurial risk-taking also encounters other problems. One is that entrepreneurs may display different degrees of risk propensity. According to Brockhaus (1980), for example, risk propensity of established entrepreneurs might be different from that of new entrepreneurs. Schwer and Yucelt (1984) studied small business entrepreneurs in Vermont and found that they differed in their propensity toward risk-taking. Another problem is that risk-taking propensity is also subject to change because it depends to a large degree on the environment and perceived situations (Daly \& Wilson, 2001).

Research has suggested that people are more likely to take risks when the outcome of the action is affected by their own skills rather than by chance (Heath \& Tversky, 1991). Macko and Tyszka (2009) hypothesized, therefore, that entrepreneurs would be more risk-prone than non-entrepreneurs in skillrelated risky situations and not in purely chance-related risky situations. They used an experimental approach with well-defined outcomes and probabilities of different choices to test the hypothesis, but it did not receive support. However, they found entrepreneurs were more optimistic. They then conducted a second experimental study with very little and vague information about outcomes and probabilities of different choices. They did find entrepreneurs made more risky choices. Finally, Macko and Tyszka argued entrepreneurs would not love risks more than other people, though they have to undertake risks. They even 
noted that entrepreneurs would try to avoid risks. Miner (1990) also argued that a key task in entrepreneurship is to avoid risk. If entrepreneurs try to avoid risks, why do they finally take risky actions? According to Macko and Tyszka (1980), self-confidence helps explain entrepreneurs' risk-taking behaviors despite their risk avoidance. This idea is consistent with the cognitive approach researchers have employed to address the limitations of trait approach.

In addition to risk-taking propensity, some other traits including need for achievement, internal locus of control and tolerance for ambiguity have also been studied. Entrepreneurs might be motivated by need for achievement (Durand \& Shea, 1974; McClelland, 1961), but empirical results have been mixed. Begler and Boyd (1987) found that entrepreneurs had higher need for achievement than the general population. Koh (1996) reported that entrepreneurs did not have higher need for achievement than managers. McClelland (1961) found that individuals with high levels of achievement often took moderate risk, while individual with low achievement were more risk taking. Hull et al. (1980) found that need for achievement was not associated with people's propensity to start risky ventures. People with high need for achievement may pursue other career options such as being a manager to achieve their goals (Cromie, 2000).

Internal locus of control may also help explain why entrepreneurs take risky actions. People would not risk their own money to create new ventures if they do not believe in their abilities to control the outcome (Mueller \& Thomas, 2001). Empirical studies have shown mixed results. Cromie and Johns (1983) found that entrepreneurs had higher internal control than experienced managers. Shapero (1975) had similar findings: the entrepreneur group scored higher on internal control than the non-entrepreneur groups. Cromie et al. (1992) found entrepreneurs and managers did not differ in internal control.

Entrepreneurship involves uncertainty. Tolerance for ambiguity is likely to facilitate risk-taking. According to Mitton (1989: 15), entrepreneurs "eagerly undertake the unknown" and "willingly seek out and manage uncertainty." If people are unwilling to face uncertainty, they would not take risks to pursue entrepreneurial opportunities (Bhide, 2000). Koh (1996) reported that people who were entrepreneurialinclined tolerated more ambiguity than those who were not. Despite the importance of tolerance for ambiguity, Bhide (2000) also noted that for individuals to venture into an unknown world, they also need to possess other characteristics such as skills.

\section{Demographic Approach}

Entrepreneurial risk-taking may be affected by individuals' demographic background: gender, age, education, socioeconomic status, experience, etc. Byrnes and colleagues (1999) found that men were more risk-taking than women in 14 of 16 domains studied. Therefore, men could be more likely to display entrepreneurial behaviors than women (Crant, 1996). Education might facilitate entrepreneurial activities given the importance of skills. Souitaris et al. (2007) found education had positive impact on entrepreneurial intention, but Oosterbeek et al. (2010) reported negative impact of education on students' intention to start a business. People's socioeconomic status may encourage or discourage their intention to engage in entrepreneurial activities. It may be true that rich people, who have sufficient funds for investment, are more likely than non-rich salaried employees to risk a portion of their money to be entrepreneurs. It may also be true that non-rich salaried employees are more likely than rich people to start a risky venture because they want to get rich. Goss (2004) argued that low status might motivate people to run their own business in order to avoid "shame," but Bide (2000) noted that individuals with middle-class status could be more likely to start their own business than those having extremely wealthy or extremely deprived backgrounds. Experience affects decision-making in the real world (Mishra, 2014). It has been reported that entrepreneurial experience had positive impact on new venture creation (Davidsson \& Honig, 2003; Delmar \& Davidsson, 2000). However, people do not have to possess entrepreneurial experience to create new ventures.

It seems demographic approach alone cannot explain entrepreneurial risk-taking behaviors. Why should rich people create their own business given that they are already rich? Why should non-rich salaried employees put their limited funds to a risky venture? Why do many educated people prefer being employed when they have the knowledge and skills to start their own business? It might be helpful to look for explanations beyond the demographic variables. 


\section{Environmental Approach}

The environment may shape people's entrepreneurial behaviors. The literature has identified the impact of both the immediate and the broad environment. The immediate environment largely takes the form of social context in which individuals interact with and influence each other. According to Carsrud and Johnson (1989), entrepreneurial behaviors need to be studied in the social context. It affects individual behaviors through peer effects (Lahno \& Serra-Garcia, 2015), role model (Brockhaus \& Horwitz, 1986), role expectations, and social pressures to conform (Moscovici, 1985). Lopera and Marchand (2018) conducted two risk-taking experiments with young Ugandan entrepreneurs and found participants tended to make more risky choices in the second experiment if the peers they discussed with made more risky choices in the first experiment, suggesting peer effects on entrepreneurial risk-taking. Role model, another contextual variable, can also shape people's entrepreneurial behaviors. Brockhaus and Horwitz (1986:43) noted "...from an environmental perspective, most entrepreneurs have a successful role model, either in their family or the workplace." Wang and Wong (2004) surveyed 5,326 undergraduates in Singapore and found that respondents whose families ran a business were more interested in entrepreneurship. De Wit and Van Winden (1989) reported that in Netherlands, self-employed fathers could decisively affect their children's choice to become self-employed.

Entrepreneurial risk-taking may also be affected by broad environmental variables such as political (Gnyawali \& Fogel, 1994), economic (Okamuro, 2008), and cultural (Mitchell et al, 2000). According to Gnyawali \& Fogel (1994), for example, the government may encourage entrepreneurial activities by creating an "enterprise culture" in which entrepreneurs of new ventures take reasonable risks and seek profits. The government may also dampen entrepreneurial spirit through imposing unfavorable policies. Favorable economic conditions are likely to stimulate more entrepreneurial activities, but Okamuro (2008) reported that districts with high expected profits did not have high start-up ratios. When comparing the impact of the social context and the broad environment on entrepreneurial behaviors, Carsrud and colleagues (1987) argued that the former exerts more impact than the latter.

\section{Cognitive Approach}

According to Baron (2004), the cognitive approach is a valuable tool for answering some basic questions in the field of entrepreneurship, including "why some persons but not others choose to become entrepreneurs?" (P223). This approach proposes that the mental processes - the cognitive mechanisms through which we acquire, store, transform, and use information - will influence "everything we think, say, or do" (P221). Why do entrepreneurs engage in risky activities, though they do not appear to be risk takers or may not have higher risk propensities? The cognitive perspective suggests that entrepreneurs are likely to perceive things in a way that the risks involved look smaller in magnitude. Existing cognitive research on entrepreneurship has focused on cognitive processes, cognitive structures, and social cognition.

Cognitive processes refer to how information is received and utilized by individuals (Walsh, 1995). They are likely to affect entrepreneurial decision-making. Palich and Bagby (1995) used a scenario approach to determine if entrepreneurs exhibited evidence of unique cognitive categorization processes. They found that entrepreneurs did not think of themselves as being any more predisposed to taking risks than non-entrepreneurs. Instead, they perceived business scenarios more positively. Zaleskiewicz et al (2020) compared entrepreneurs and non-entrepreneurs (full-time employees) based on ten risky scenarios which included both business and non-business risks. They found that entrepreneurs were not different from non-entrepreneurs in either their risk attitudes or willingness to take non-business risks. However, entrepreneurs produced more positive and vivid mental images of risk consequences and declared a more readiness to take business risks. Therefore, they argued entrepreneurial risk-taking is related to mental imagery which is a cognitive process.

Human beings are often far from totally rational when processing information, so cognitive biases exist. According to Baron (2004), cognitive biases play an important role in entrepreneurial decision-making. Examples include overconfidence, overoptimism, illusion of control, and belief in the law of small numbers. To examine the impact of cognitive biases on venture creation, Simon and colleagues (2000) surveyed 191 MBA students and found that both illusion of control and belief in the law of small numbers decreased 
one's perception of the level of risk associated with creating a venture. However, they did not find the positive impact of overconfidence on reduction of perceived risk.

A cognitive structure is a hypothetical link between a stimulus and an ensuing judgment (Bieri et al., 1966). It is often represented by constructs like script, schema, and knowledge structure (Gioia \& Poole, 1984). Mitchell et al (2000) identified three types of cognitive scripts: arrangements scripts (knowledge structures individuals have about the use of specific arrangements such as the resources, relationships and assets necessary for an action), willingness scripts (knowledge structures informing commitment to an action), and ability scripts (knowledge structures individuals have about the skills and capabilities for an action). They used data from seven countries to examine the relationships between the three types of cognitive scripts and entrepreneurial decision making. They found arrangements, willingness, and ability scripts were positively associated with people's decisions to create risky ventures.

The social context can affect people's cognition, termed as social cognition. It focuses on how people process information about other people and the social situations (Mitchell et al, 2000). As discussed above, peer effects, role model, role expectations, and social pressures to conform are examples of how the social context might affect entrepreneurial risk-taking. Actually, they exert an influence through cognitive mechanisms because they affect how individuals process information from the social environment. Social cognition provides an approach to integrate both the individual and the environment. In the three types of cognitive scripts studied by Mitchell et al (2000), arrangement scripts (individual level) are informed by the social context (environmental level). In other words, the social context helps the individual cognitively prepared through providing resources necessary for venture creation.

Arguably, the cognitive approach provides important implications for explaining entrepreneurial risky behaviors. Not all entrepreneurs have high risk propensity. Some even try to avoid risks. Why do they still pursue risky entrepreneurial endeavor? A reasonable explanation is that they perceive lower risk due to cognitive biases or other cognitive mechanisms. However, Baron (2004) also noted that cognition is not the only explanation. Traits, motives, skills, and abilities also play a role. In addition, economic and social factors affect entrepreneurship too. Most studies on entrepreneurial cognitions have compared entrepreneurs and non-entrepreneurs. One assumption behind the cognitive approach is that entrepreneurs have some unique cognitions, implying a trait approach. Forbes (1999) argued that we also need to understand cognitive differences among entrepreneurs.

\section{Summary}

Four approaches have been used to examine entrepreneurial risk-taking: trait approach, demographic approach, environmental approach, and cognitive approach. Each approach has attempted to identify some key influencing factors, but empirical results have been inconclusive, suggesting that each approach alone is not sufficient to explain why entrepreneurs take risks. The influencing factors identified by the four approaches fall into two categories: individual variables and environmental situations. Broadly, any decision-making behavior results from the interactions between the individual and the environment (Dall et al, 2012). Entrepreneurs also interact with the environment to make decisions. Therefore, Carsrud and Hohnson (1989) called for an integration between the individual variables and the social context to study entrepreneurial behaviors. Mitchell et al (2000) used "person-in-situation" to explain why entrepreneurs start risky ventures. The "situation" in their study is also the social context. The person-in-situation approach is based on the social cognitive perspective: individuals exist within a social situation and the individual behavior results from his or her processing information about the situation (Fiske \& Taylor, 1984).

The social cognitive perspective provides an approach to integrate the individual and the environment, but the environment is reduced to the social context. Other environmental factors such as economic conditions may also affect entrepreneurs' risk-taking behaviors (Baron, 2004). In this study, I extend the social cognitive perspective and develop a more integrative framework based on risk-sensitivity theory to explain entrepreneurial risk-taking. 


\section{RISK-SENSITIVITY THEORY}

Risk sensitivity theory was developed by behavioral ecologists to examine the foraging behavior of animals (Stephens \& Krebs, 1986). According to the theory, a forager's risky decision-making is regulated by its need level. If two foraging patches are the same in the mean caloric return, but different in outcome variance, then, the forager's need would determine the best choice. If the forager needs more than the mean caloric return to survive, it would choose the higher variance (i.e., riskier) patch in order to increase the chance of meeting that need. In contrast, if the forager's survival need is equal to or less than its mean return, it would choose the low variance (i.e., safer) patch. Risk sensitivity theory has received robust empirical support from non-human animal studies (e.g., Real \& Caraco, 1986).

Risk sensitivity theory has recently been applied in the human context and empirical evidence has confirmed its power in predicting human risk-taking behaviors (e.g., Mishra \& Lalumière, 2010; Mishra et al., 2012; Mishra, 2014; Rode et al, 1999). According to Mishra (2014), the main idea behind risk sensitivity theory is that need motivates human risk-taking behaviors. Decision makers shift from risk aversion to risk preference in situations of need when lower risk options are not likely to meet the need. For example, a person with a pressing $\$ 5,000$ debt would prefer a $10 \%$ chance of winning $\$ 5,000$ over winning $\$ 500$ with certainty. A need is defined as a disparity between an individual's present state and desired state (i.e., goal). It can be either an aspirational goal or a minimal acceptable threshold (e.g., survival). When the two needs are not reconcilable, people would prefer the minimal acceptable threshold. The application of risksensitivity theory involves several steps: defining the need, identifying potential decision options that differ in risk, choosing an option that is likely to meet the need, and taking risky actions. Decision-makers may not seek to maximize desired outcomes. Instead, they try to avoid results that fail to meet their need. Therefore, risk-sensitivity theory is a satisfying theory of decision making, seeking "good-enough", not optimal decisions.

Risk-sensitivity theory integrates both individual and environmental variables when predicting decision-making under risk. Those variables either shape individuals' need or facilitate actual risky actions to fulfil the need. Individual variables include personality traits and demographic factors. Personality traits such as risk-taking propensity are relatively stable individual characteristics which can facilitate actual risktaking in order to meet the need (Mishra \& Lalumière, 2011). The impact of personality traits on risk-taking appears to be domain-general (Misha et al, 2011). Demographic factors may affect individuals' perceived need. Risk-taking may thus be engaged in to meet the need. For example, people with poor economic conditions would perceive an economic need, that is, a disparity between the present economic status and the desired economic status. As a result, they are likely to engage in risky actions to meet their need (Wohl, et al, 2014).

Though need, a key component of the risk-sensitivity theory, is individual-specific, it is not isolated from the environment. The environment can shape individuals' perception of need through providing information. Mishra (2014) reasoned, therefore, risk-sensitivity theory "uses cognitive mechanisms that are sensitive to the structure of information in the environment" (P300) and "decision makers acquire environmentally specific information about decision options from [personal] experience" (P299). For example, social context can shape people's need and their behaviors through role expectations and social pressure to confirm (Moscovici, 1985). Because the environment is subject to change, risk-sensitivity theory takes an evolutionary approach. It suggests that "risky behavior is, in fact, an adaptive response to various environmental and social circumstances, taking into account developmental influences and individual differences" (P301).

\section{ENTREPRENEURIAL RISK-TAKING: AN INTEGRATIVE FRAMEWORK}

Risk-sensitivity theory offers a need-based framework for predicting risk-taking behaviors, where a need is defined as the disparity between individuals' present state and desired state or goal. What do entrepreneurs need or desire? The literature has identified both economic and non-economic reasons for which people take risky entrepreneurial actions. They may pursue social distinction, self-fulfillment, and 
joy of creation, getting things done, and exercising energy, as well as economic gains (Van Praag, 1999). They may also pursue independence (Zaleskiewicz et al, 2020) and achievement (Begler \& Boyd, 1987). Based on risk-sensitivity theory, these needs would drive people to engage in entrepreneurship if other career options cannot meet their needs or there are no other options. This need-based framework can be used to interpret the results of existing research on entrepreneurial risk-taking.

\section{Interpreting Entrepreneurial Risk-Taking}

Trait Approach

Trait approach has identified a number of psychological or personality traits including risk-taking propensity, need for achievement, internal locus of control and tolerance for ambiguity. Among them, risktaking propensity has been researched extensively, but empirical studies have generated conflicting results. Why are people with both high and low risk-taking propensities likely to take risky entrepreneurial actions? Risk-sensitivity theory provides an explanation. According to Mishra (2014), risk-taking can be domaingeneral, though it is more likely domain-specific. Relatively stable individual characteristics may facilitate risk-taking in different domains. In the entrepreneurship field, high risk-taking propensity is likely to encourage people, particularly those who have to incur high opportunity costs, to move to the next step: taking the actual action. For example, educated people might be discouraged to pursue a risky selfemployed career (Oosterbeerk et al, 2010), but if they do have an intention to start their own business to fulfil some entrepreneurial needs, those who have high risk-taking propensity would take the actual action more quickly. People who are risk averse can also become entrepreneurs (Miner \& Raju, 2004). Risksensitivity theory suggests a pre-condition: less risky options are unlikely to meet their needs or not available. Entrepreneurs may not take risks deliberately (Cromie \& O'Domoghue, 1992). Like nonentrepreneurs, they are also sensitive to risk. But when they do take a risk, need fulfilment would be a powerful explanation.

Internal locus of control and tolerance for ambiguity may also play a role in entrepreneurial risk-taking. Like risk-taking propensity, they could facilitate actual risky actions. However, these traits alone are not sufficient in explaining entrepreneurial behaviors. For example, empirical evidence suggests entrepreneurs may or may not have higher internal control than managers (Cromie \& Johns, 1983; Cromie et al, 1992; Shapero, 1975). To create a business, they still need to possess other characteristics such as skills (Bhide, 2000). This argument is consistent with risk-sensitivity theory. According to Mishra (2014), decision makers take risks to meet their needs, but they also seek to "minimize the probability of experiencing outcomes that fail to meet their needs." (P). In other words, they seek gains but not at a cost of loss. Skills are more likely to help reduce the probability of experiencing loss than personality traits like internal control. Risk-sensitivity theory has emphasized the importance of experience in effective risky decisionmaking (Mishra \& Lalumiere, 2010).

Need for achievement is an aspirational goal, a need entrepreneurs may pursue. It may drive entrepreneurial behaviors (Begler \& Boyd, 1987), but empirical support has not been strong (Hull et al., 1980; Koh, 1996). A possible reason is that need for achievement may also motivate people to become a manager (Cromie, 2000), which is less risky. This explanation is consistent with risk-sensitivity theory: people would compare different options and choose a less risky one to meet their needs.

\section{Demographic Approach}

Existing studies have identified some demographic variables that may affect entrepreneurial risktaking: gender (Byrnes et al, 1999), education (Souitaris et al, 2007), social status (Goss, 2004), and experience (Davidson \& Honig, 2003). Risk-sensitivity theory recognizes individual differences in risky decisions. According to Mishra (2014), for example, young males in a competitive environment more often experience relative disparity than females between their present state and desired goals such as social status. As a result, they are more likely to engage in risk-taking behaviors. Demographic approach to entrepreneurship has generated conflicting results. For example, education has been found to affect entrepreneurial intention to start a new business both positively and negatively (Oosterbeek et al, 2010; Souitaris et al, 2007). Risk-sensitivity theory offers an explanation. People's needs are likely to be shaped 
by education. With more knowledge and skills, they may not be satisfied anymore with limited salaries offered by their employers. In addition, they may also pursue more independence. Being an entrepreneur is an option to meet their needs. Knowledge and skills give them confidence. Therefore, educated people could confidently take entrepreneurial actions. On the other hand, education may also help people secure decent jobs which would be good enough to meet their economic and non-economic needs. Those who are risk-averse are less likely to give up what they have already gained to pursue risky self-employment.

\section{Environmental Approach}

Environmental approach examines the impact of both the social context (immediate environment) and the broad environment on entrepreneurial behaviors. According to Mishra (2014), need is "largely sensitive to environmental inputs" (P297), whether the environment is immediate (social) or broad. From this point of view, there is a connection between risk-sensitivity theory and environmental approach to entrepreneurial risk-taking. Peer effects, role model, role expectations and social pressures to confirm are important mechanisms through which the social context exerts an influence. They imply the desired state (i.e., need) for the individuals to achieve in the social environment. It can be argued, therefore, that these mechanisms affect entrepreneurial behaviors through shaping individuals' needs. Most entrepreneurs have a successful role model (Brockhaus \& Horwitz, 1986). The role model creates a "need" for would-be-entrepreneurs to fulfil.

The broad environment such as favorable economic conditions and government policies may encourage entrepreneurship through enhancing people's willingness and/or ability to create new ventures (Gnyawali \& Fogel, 1994). Arguably, people's willingness to create new ventures is need-driven, while people's ability to create new ventures can facilitate the actual risky actions. However, favorable environmental situations may not always encourage entrepreneurship. For example, Okamuro (2008) reported that more economic opportunities did not lead to more start-ups. Risk-sensitivity theory helps explain the conflicting results. A strong economy is likely to generate more employment opportunities. People would favor employment over risky self-employment to meet their needs.

\section{Cognitive Approach}

Cognitive approach has identified three mechanisms though which cognition shapes entrepreneurial behaviors: cognitive processes, cognitive structure, and social cognition. Cognitive processes emphasize cognitive biases when people perceive things. In the entrepreneurship literature, scholars have agreed to a lesser degree that entrepreneurs have high risk-taking propensity, but to a larger degree that entrepreneurs perceive less risks than non-entrepreneurs. Cognitive biases help explain why risk averse people may take risky entrepreneurial actions. Cognitive mechanisms are important in risk-sensitivity theory (Mishra, 2014). It also emphasizes the role of cognitive biases in shaping risky behaviors but within the need-based framework. According to Mishra, need could affect people's perception of losses and gains of decision options. When people are in conditions of high need, they would emphasize the low probability of large gains and deemphasize the high probability of losses involved in risky decisions. They are likely to feel more comfortable about risky decisions, suggesting that people in conditions of high need would perceive less risk, which is consistent with cognitive approach to entrepreneurial risk-taking. Empirical evidence suggests that people do overestimate or underestimate events based on situations, leading to different risky choices (Hertwig et al., 2004).

A cognitive structure serves as a link between an event or situation and the subsequent decision. It can be illustrated by scripts. Mitchell et al (2000) reported that arrangements scripts, willingness scripts, and ability scripts had positive impact on people's decision to create risky ventures, which is consistent with risk-sensitivity theory. On the one hand, people should have the willingness to pursue a risky option (willingness scripts) if less risky options cannot meet their needs; on the other hand, they want to minimize loss when taking the risk. If they possess necessary resources (informing arrangements scripts) and skills (informing ability scripts), they would be in a better position to minimizes loss. As a result, they would be more likely to move forward to take the actual action. 
Social cognition is associated with individuals' processing of information from the social environment. It offers a theoretical framework integrating both the individual and social environment variables. Risksensitivity theory can be viewed as an extension of the social cognition perspective for two reasons. First, it also uses cognitive mechanisms; second, it incorporates both the social context and the broad environment in its need-based framework.

\section{An Integrative Framework}

As discussed above, risk-sensitivity theory is able to interpret the results of existing approaches to entrepreneurial risk-taking. It does not reject the value of those different approaches. Instead, it either confirms them or reconciles them by offering a new perspective. In addition, it provides implications for some unanswered questions in the entrepreneurship literature. For example, Macko and Tyszka (2009) noted that we need an explanation why people who are not risk-prone still pursue objectively risky entrepreneurial endeavor. Scholars are still looking for an answer (Zaleskiewicz et al, 2020). Risksensitivity theory offers a simple and clear explanation: other less risky options cannot meet their needs.

According to Mishra (2014), risk-sensitivity theory "is an excellent starting point for building an integrated, comprehensive theory of decision-making [under risk]" (P297). Though the theory may be criticized as being too general, its main virtue is its broad generality and can explain patterns of risky decisions in a wide array of domains. Entrepreneurs make risky decisions. Existing approaches to entrepreneurial risk-taking have adopted either individual- or environmental-level analysis, leading to inconsistent or conflicting results. Scholars have called for a framework integrating both individual variables and environmental situations. I argue that risk-sensitivity theory provides implications for building such an integrative framework for two reasons: first, it reconciles existing approaches to entrepreneurial risk-taking as explained previously; second, it integrates both individual and environmental variables through cognitive mechanisms. The two levels of variables interact with each other to shape personal needs, affect decision options and choice of option, and finally facilitate actual actions. Figure 1 illustrates entrepreneurial risk-taking based on risk-sensitivity theory.

FIGURE 1

\section{ENTREPRENEURIAL RISK-TAKING: A NEED-BASED FRAMEWORK}

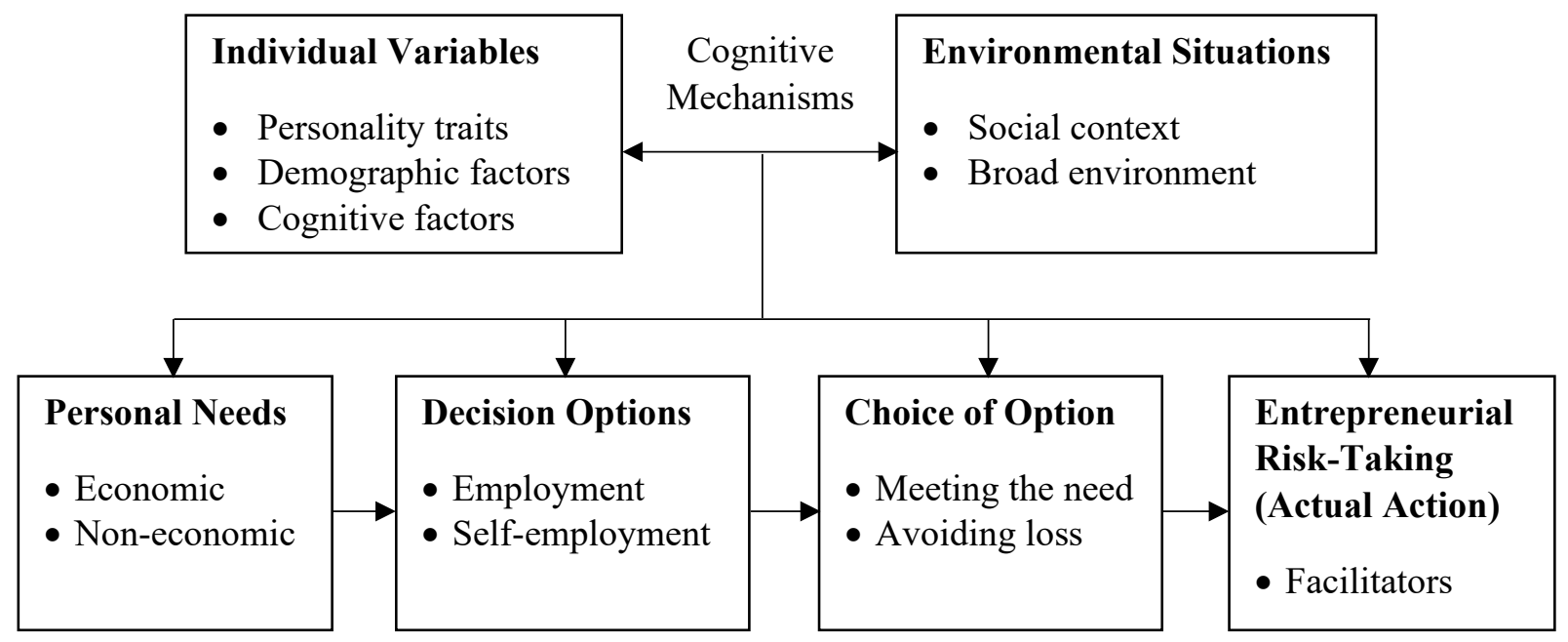

\section{DISCUSSION}

People often make rational decisions under predictable conditions (Kahneman \& Tversky, 1979). If outcomes and probabilities of alternative actions are well-defined, entrepreneurs would not display more risk-taking than non-entrepreneurs whether decision-making requires skills or is purely chance-related 
(Macko \& Tyszka, 2009). Therefore, entrepreneurs do not appear to take risks deliberately. However, entrepreneurial actions involve uncertainty. Outcomes and probabilities of alternative actions are often not clear. Why do entrepreneurs still take risky actions when they are not risk-prone or are even risk-averse? The explanation from risk-sensitivity theory is simple and straightforward: to fill the discrepancy between the present state and the desired state. It offers a solution to some main problems from which existing approaches to entrepreneurial risk-taking suffer.

First, much previous research has assumed entrepreneurs as a group are homogeneous. They possess some common psychological traits or cognitive factors that drive them to take risky actions. This assumption is intuitively appealing, but has not received strong empirical support. Though risk-sensitivity theory recognizes the impact of relatively stable individual characteristics on risk-taking, it does not assume those characteristics distinguish risk-takers from risk-avoiders. Instead, it assumes risk-taking is more likely to occur in specific situational circumstances, which helps explain why entrepreneurs come from a variety of backgrounds: rich or poor, educated or less educated, skilled or less skilled, etc.

Second, entrepreneurial risk-taking is a dynamic process and is subject to change based on situations (Carsrud \& Johnson, 1989). Even the proposed entrepreneurial "traits" like risk-taking propensity are also subject to change (Daly \& Wilson, 2001). The evolutionary approach adopted by risk-sensitivity theory captures the dynamic nature of entrepreneurship. The theory suggests that risky behavior is an individual's adaptive response to various environmental situations. Any need is not treated as being stable. New needs can be generated from the interactions between the individual and the environment. As a result, entrepreneurs take risks in response to new needs.

Third, it has long been recognized that any decision-making behavior is a result of individualenvironment interactions (Dall et al, 2012). Existing approaches to entrepreneurial risk-taking suffer from adopting either the individual- or environmental-level analysis. Though entrepreneurship scholars have called for an integration between individual and environmental variables for a long time (Carsrud \& Hohnson, 1989), an integrative framework has been lacking. Risk-sensitivity theory may serve as a starting point for building such a framework for explaining entrepreneurial risk-taking. Both the individual and environmental variables are integrated into a need-based framework. The framework recognizes the value of different approaches to entrepreneurial risk-taking. At the same time, it also addresses the limitations of each approach if used alone.

Risk-sensitivity theory offers a promising approach to understanding entrepreneurial risk-taking, but it is still a broad framework. Future research may examine this framework in detail. First, entrepreneurial needs can be both economic and non-economic. Which type of needs has more impact on entrepreneurial risk-taking and under what circumstances? For example, both rich and poor people are likely to start their own business. Their needs can be different. It would be interesting to examine how entrepreneurial risk taking is affected by different needs. Second, people have two broad career options to meet their needs: employment or self-employment. Clearly, employment is less risky. Based on risk-sensitivity theory, if people cannot have their needs to be met through employment, they would choose risky self-employment. The theory also suggests that people do not seek gain at a loss. When employed people choose to run their own business, they have low probabilities of achieving the expected gain in the beginning. According to Kahneman and Tversky (1979), decision makers often overweight outcomes that are certain over those that involve probabilities. When employed people become self-employed, losing salaries is a sure thing. How do they weigh the possible gains and sure loss? How would their comparisons be affected by their needs? Third, both risk-prone and risk-averse people are likely to pursue the entrepreneurial endeavor. Risksensitivity theory only provides broad explanations: they take entrepreneurial actions when other less risky options cannot meet their needs. Specifically, how do the two groups of people move forward to make the final decision when they know they do not have less risky options to meet their needs? For example, would risk-averse people conduct more research before making the final decision? Would they take a longer time during the process of decision-making? 


\section{CONCLUSION}

Broadly, people make decisions to solve problems. From this point of view, all decisions involve considerations of needs and fulfilment of needs. It can be argued, therefore, risky decisions are need-driven. The need-based approach proposed by risk-sensitivity theory offers an explanation to entrepreneurial risktaking and an answer to some unanswered questions in the field of entrepreneurship.

\section{REFERENCES}

Astebro, T.B., Herz, H., Nanda, R., \& Weber, R.A. (2014). Seeking the roots of entrepreneurship: Insights from behavioral economics. Journal of Economic Perspectives, 28(3), 49-70.

Baron, R.A. (2004). The cognitive perspective: A valuable tool for answering entrepreneurship's basic "why" questions. Journal of Business Venturing, 19, 221-239.

Begley, T., \& Boyd, D. (1987). Psychological characteristics associated with performance in entrepreneurial firms and smaller businesses. Journal of Business Venturing, 2, 79-93.

Bhide, A.V. (2000). The origin and evolution of new business. New York: Oxford Press, Chapter 4 "Distinctive Qualities".

Bieri, J., Atkins, A.L, Briar, S., Leaman, R.L., Miller, H., \& Tripodi, T. (1966). Clinical and Social Judgment: The discrimination of behavioral information. John Wiley \& Sons, Inc.

Brockhaus, R.H. (1980). Risk taking propensity of entrepreneurs. Academy of Management Journal, 23(3), 509-520.

Brockhaus, R.H., \& Horowitz, P. (1986). The psychology of the entrepreneur. In D. Sexton \& R. Smilor (Eds.), The Art and Science of Entrepreneurship. Ballinger, Cambridge, MA.

Byrnes, J.P., Miller, D.C., \& Schafer, W.D. (1999). Gender differences in risk taking: A meta-analysis. Psychological Bulletin, 125, 367-383.

Carsrud, A.L., \& Johnson, R.W. (1989). Entrepreneurship: A social psychological perspective. Entrepreneurship and Regional Development: An International Journal, 1(1), 21-31.

Carsrud, A.L., Gaglio, C.M., \& Olm, K.W. (1987). Entrepreneurs - Mentors, networks, and successful new venture development: An exploratory study. American Journal of Small Business, 12(1), 1318.

Crant, J.M. (1996). The proactive personality scale as a predictor of entrepreneurial intentions. Journal of Small Business Management, 34(3), 42-49.

Cromie, S. (2000). Assessing entrepreneurial inclinations: Some approaches and empirical evidence. European Journal of Work and Organizational Psychology, 9(1), 7-30.

Cromie, S., \& Johns, S. (1983). Irish entrepreneurs: Some personal characteristics. Journal of Organization Behavior, 4, 317-324.

Cromie, S., \& O’Donoghue, J. (1992). Assessing entrepreneurial inclinations. International Small Business Journal, 10, 66-73.

Cromie, S., Callaghan, I., \& Jansen, M. (1992). The entrepreneurial tendencies of managers: A research note. British Journal of Management, 3(1), 1-5.

Dall, S.R.X., Gosling, S.D., Brown, G.D., Dingemanse, N., Erev, I., Kocher, M., \& Wolf, M. (2012). Variation in decision making. In P. Hammerstein \& J.R. Stevens (Eds.), Evolution and the mechanisms of decision making (pp. 243-272). Cambridge, MA: MIT Press.

Daly, M., \& Wilson, M. (2001). Risk taking, intrasexual competition, and homicide. Nebraska Symposium on Motivation, 47, 1-36.

Davidsson, P., \& Honig, B. (2003). The role of social and human capital among nascent entrepreneurs. Journal of Business Venturing, 18(3), 301-331.

De Wit, G., \& Van Winden, F.A. (1989). An empirical analysis of self-employment in the Netherlands. Small Business Economics, 1(4), 263-272.

Delmar, F., \& Davidsson, P. (2000). Where do they come from? Prevalence and characteristics of nascent entrepreneurs. Entrepreneurship \& Regional Development, 12(1), 1-23. 
Durand, D., \& Shea, D. (1974). Entrepreneurial activity as a function of achievement motivation and reinforcement control. Journal of Psychology, 88, 57-63.

Fiske, S.T., \& Taylor, S.E. (1984). Social cognition. Reading, MA: Addison-Wesley.

Forbes, D.P. (1999). Cognitive approaches to new venture creation. International Journal of Management Reviews, 1(4), 415-439.

Gartner, W.B., Shaver, K.G., Gatewood, E., \& Katz, J.A. (1994). Finding the entrepreneur in entrepreneurship. Entrepreneurship: Theory and Practice, 18(3), 5-9.

Gasse, Y. (1982). Elaborations on the psychology of the entrepreneur. In C.A. Kent, D.L. Sexton, \& K.H. Vesper (Eds.), Encyclopedia of Entrepreneurship (pp. 57-71). Englewood Cliffs, NJ: Prentice Hall.

Gioia, D.A., \& Poole, P.P. (1984). Scripts in organizational behavior. Academy of Management Review, 9(3), 449-459.

Gnyawali, D.R., \& Fogel, D.S. (1994). Environments for entrepreneurship development: Key dimensions and research implications. Entrepreneurship: Theory and Practice, 18(4), 43-62.

Goss, D. (2005). Entrepreneurship and 'the social': Towards a deference-emotion theory. Human Relations, 58(5), 617-636.

Heath, C., \& Tversky, A. (1991). Preference and belief: Ambiguity and competence in choice under uncertainty. Journal of Risk and Uncertainty, 4, 5-28.

Hertwig, R., Barron, G., Weber, E.U., \& Erev, I. (2004). Decisions from experience and the effect of rare events in risky choice. Psychological Science, 15, 534-539.

Hornaday, J.A. (1982). Research about living entrepreneurs. In C.A. Kent, D.L. Sexton, \& K.H. Vesper (Eds), Encyclopedia of Entrepreneurship. Englewood Cliffs, NJ: Prentice Hall.

Hull, D.L., Bosley, J., \& Udell, G.G. (1980). Renewing the hunt for the Heffalump: Identifying potential entrepreneurs by personality characteristics. Journal of Small Business Management, 18(1), 1118.

Kahneman, D., \& Tversky, A. (1979). Prospect theory: An analysis of decision under risk. Econometrica, 47, 313-327.

Koh, H.C. (1996). Testing hypotheses of entrepreneurial characteristics. Journal of Managerial Psychology, 11(3), 12-25.

Lahno, A.M., \& Serra-Garcia, M. (2015). Peer effects in risk taking: envy or conformity? Journal of Risk Uncertainty, 50(1), 73-95.

Leibenstein, H. (1968). Entrepreneurship and development. American Economic Review, 58, $72-83$.

Lopera, M.A., \& Marchand, S. (2018). Peer effects and risk-taking among entrepreneurs: Lab-in-the-field evidence. Journal of Economic Behavior and Organization, 150, 182-201.

Macko, A., \& Tyszka, T. (2009). Entrepreneurship and risk taking. Applied Psychology: An International Review, 58(3), 469-487.

McClelland, D.C. (1961). The Achieving Society. D. Van Nostrand, Princeton, NJ.

Mill, J.S. (1848). Principles of political economy with some of their applications to social philosophy. In J.A. Schumpeter (Ed.), History of Economic Analysis. New York: Oxford University Press, 1954.

Miner, J.B. (1990). Entrepreneurs, high growth entrepreneurs and managers: Contrasting and overlapping motivational patterns. Journal of Business Venturing, 5(4), 221-234.

Miner, J.B., \& Raju, N.S (2004). Risk propensity differences between managers and entrepreneurs and between low- and high-growth entrepreneurs: A reply in a more conservative vein. Journal of Applied Psychology, 89(1), 3-13.

Mishra, S. (2014). Decision-making under risk: Integrating perspectives from biology, economics, and psychology. Personality and Social Psychology Review, 18(3) 280-307.

Mishra, S., \& Lalumière, M.L. (2010). You can't always get what you want: The motivational effect of need on risk-sensitive decision-making. Journal of Experimental Social Psychology, 46, 605-611.

Mishra, S., Gregson, M., \& Lalumière, M.L. (2012). Framing effects and risk-sensitive decision-making. British Journal of Psychology, 103, 83-97. 
Mitchell, R.K., Smith, B., Seawright, K.W., \& Morese, E.A. (2000). Cross-cultural cognitions and the venture creation decision. Academy of Management Journal, 43(5), 974-993.

Mitton, D.G. (1989). The compleat entrepreneur. Entrepreneurship Theory and Practice, 13(3), 9-19.

Moscovici, S. (1985). Social influence and conformity. In G. Lindzey \& E. Aronson (Eds.), The Handbook of Social Psychology. New York: Random House.

Mueller, S.L., \& Thomas, A.S. (2001). Culture and entrepreneurial potential: A nine country study of locus of control and innovativeness. Journal of Business Venturing, 16(1), 51-75.

Mullins, J.W., \& Forlani, D. (2005). Missing the boat or sinking the boat: A study of new venture decision making. Journal of Business Venturing, 20(1), 47-69.

Okamuro, H. (2008). How different are the regional factors of high-tech and low-tech start-ups? Evidence from Japanese manufacturing industries. International Entrepreneurship and Management Journal, 4(2), 199-215.

Oosterbeek, H., van Praag, M., \& Ijsselstein, A. (2010). The impact of entrepreneurship education on entrepreneurship skills and motivation. European Economic Review, 54(3), 442-454.

Palich, L.E., \& Bagby, R.D. (1995). Using cognitive theory to explain entrepreneurial risk taking: Challenging conventional wisdom. Journal of Business Venturing, 10, 425-438.

Real, L., \& Caraco, T. (1986). Risk and foraging in stochastic environments. Annual Review of Ecology and Systematics, 17, 371-390.

Rode, C., Cosmides, L., Hell, W., \& Tooby, J. (1999). When and why do people avoid unknown probabilities in decisions under uncertainty? Testing some predictions from optimal foraging theory. Cognition, 72, 269-304.

Schwer, K., \& Yucelt, U. (1984). A study of risk-taking propensities among small business entrepreneurs and managers: An empirical evaluation. American Journal of Small Business, VIII(3), 31-40.

Shapero, A. (1975). The displaced, uncomfortable entrepreneur. Psychology Today, 9(6), 83-88.

Simon, M., Houghton, S.M., \& Aquino, K. (2000). Cognitive biases, risk perception, and venture formation: How individuals decide to start companies. Journal of Business Venturing, 15(2), $113-134$.

Souitaris, V., Zerbinati, S., \& Al-Laham, A. (2007). Do entrepreneurship programmes raise entrepreneurial intention of science and engineering students? The effect of learning, inspiration and resources. Journal of Business Venturing, 22(4), 566-591.

Stephens, D.W., \& Krebs, J.R. (1986). Foraging theory. Princeton, NJ: Princeton University Press.

Stewart, W.H., \& Roth, P.L. (2001). Risk propensity differences between entrepreneurs and managers: A meta-analytic review. Journal of Applied Psychology, 86(1), 145-153.

Townsend, D.M., Hunt, R.A., McMullen, J.S., \& Sarasvathy, S.D. (2018). Uncertainty, knowledge problems, and entrepreneurial action. Academy of Management Annals, 12(2), 659-687.

Van Pragg, C.M. (1999). Some classic views on entrepreneurship. De Economist, 147, 311-335.

Walsh, J.P. (1995). Managerial and organizational cognition: Notes from a trip down memory lane. Organization Science, 6(3), 280-321.

Wang, C., \& Wong, P. (2004). Entrepreneurial interest in university students in Singapore. Technovation, 24(2), 163-172.

Wohl, M.J.A., Branscombe, N.R., \& Lister, J.J. (2014). When the going gets tough: Economic threat increases financial risk-taking in games of chance. Social Psychological and Personality Science, 5, 211-217.

Zaleskiewicz, T., Bernady, A., \& Traczyk, J. (2020). Entrepreneurial risk taking is related to mental imagery: A fresh look at the old issue of entrepreneurship and risk. Applied Psychology: An International Review, 69(4), 1438-1469. 